\title{
Simulation Impact of REDD Policy: Case Study of Forest Area in Indonesia
}

\author{
Irmadi Nahib, Turmudi, Sri Lestari Munajati and Rizka Windiastuti
}

\author{
Center for Research, Promotion and Cooperation, Geospatial Information Agency, \\ J1 Raya Jakarta Bogor KM 46 Cibinong, Jawa Barat, 16911, Indonesia \\ Email: irmadi.nahib@big.go.id
}

\begin{abstract}
Indonesia's forests in different periods have been deforested at different levels. Deforestation caused carbon emissions. The purposes of this study were :1) to measure deforestation and carbon emissions in period of 2005-2010 in Indonesia and 2) to find out the incentive value to be paid by the government. One method for measuring emissions from deforestation and forest degradation is GeOSIRIS model. A modeled GeOSIRIS policy used a carbon payment system to incentivize emission reductions. Data used in this study were maps of forest cover in 2005 and 2010, map of deforestation 20052010, carbon and agricultural price and driver variables for deforestation such as slope, elevation, logarithmic distance to the nearest road, logarithmic distance to the nearest provincial capital, the amount of area per pixel included in a national park, a timber plantation. The result of this study showed rate of deforestation was 4.65 million ha/5 years. The REDD policy could decrease deforestation in Indonesia by 0.66 million ha (17.45\%). Assuming that international carbon price was US\$ $10 / \mathrm{tCO}_{2}$ e, the change of emissions due to REDD was $24.75 \%$, or reduced emissions by 1.09 million $\mathrm{tCO}_{2} \mathrm{e} / 5$ years. Finally, Gross National Revenue from carbon payments (NPV 5 years) was US\$ 10.917 billion, where incentivize emission reductions to sub-national entities (NPV, 5 years) was US\$ 9.178 billion and net central government surplus from carbon payments was US\$1.739 billion (NPV, 5 years).
\end{abstract}

Keywords-deforestation, carbon emission, agricultural revenue, carbon payments, geosiris model

\section{INTRODUCTION}

Tropical forests and other vegetated landscapes like grasslands and wooded savannahs play a major role in the global carbon sequestration process and their conservation and protection offers immense potential for reducing greenhouse gas emissions and global warming [5]. Referring to [3] that clearing of primary forests also results in the destruction of unique tropical forest habitats, thus causing the loss of biodiversity.

Among tropical countries Indonesia experiences the second highest rate of deforestation. Therefore, accurate and up-to-date forest data are required to fight deforestation and forest degradation to support initiatives of climate change mitigation and biodiversity conservation policy [8]. Meanwhile [16] explained that the largest deforestation in Indonesia occurred in Kalimantan and Sumatra with a percentage of $36.32 \%$ and $24.49 \%$ respectively, followed by Sulawesi $11.00 \%$, Java $9.12 \%$, Maluku $8.30 \%$, Bali-Nusa Tenggara $6.62 \%$. Papua became the smallest area contributing to deforestation of $4.15 \%$. It could be seen that deforestation in Indonesia until 2009 was concentrated in Kalimantan and Sumatra.

Out of the 15.79 Mha of forest cover loss in Indonesia, reported 38\% (6.02 Mha) happened inside primary intact or damaged forests [10]. Meanwhile [11] said that over the study period annual primary forest cover loss increased with the highest total loss happened in 2012 (0.84Mha). The number was greater than the reported forest loss in Brazil (0.46Mha), which was the historical leader in the tropical forest clearing. Referring to [13], Borneo Island in the period 2000-2011 has deforestation amounted to 3.040 million ha, namely deforestation in peatland forests of 0.560 million $(18.42 \%)$ and deforestation in mineral land (non-peatland) for 2,480 million (81.58\%). Based on the period of time of deforestation, $48.5 \%$ of deforestation occurred in the period 2006-2011, i.e. deforestation on peatland forests of 0.334 million ha (59.69\%) and deforestation in mineral forests of 1.144 million (46.15\%). In Indonesia deforestation is usually linked with production of timber and expansion of settlement and agricultural area. When this existing trend continues without implementing any corrective measures, it is projected to result in a reduction of forest cover by $15 \%$ between 2015 and 2030, going from approximately $88,000,000$ ha to $74,994,100$ ha. On average, 830,000 ha of forest would be cleared for timber extraction or land conversion every year between 2015 and 2030. When the forest cover declines, so does the amount of carbon stored. The cumulative emissions from 2015 to 2030 due to forest loss would reach 2.5 billion $\mathrm{tCO}_{2}$, which, assuming an average carbon price of USD 5 to USD 10 per ton (based on international average market prices), would translate in a cumulative loss of about USD 10 billion to USD 25 billion between 2015 and 2030 [4].

REDD is not directed at stopping planned conversion of forests to other economic uses, nor at stopping the use of forests for timber. REDD signifies a way to value natural 
resource of carbon so that it can be considered along with other regular forest assets, when making decisions about land use and forest use [14].

In the calculation and modeling for carbon emissions, there are several methods and approaches. One model is the GeOSIRIS model developed by Jonah Busch at Conservation International. The GeOSIRIS model was originally developed as OSIRIS as a transparent decision support tool for REDD+ policy makers [7].

The GeOSIRIS modeler is different from the REDD modeler found in Land Change Modeler (LCM). The REDD modeler in LCM predicts how carbon emissions and deforestation would change if a certain reference area were shielded from deforestation. Meanwhile, the GeOSIRIS modeler adopts an alternate strategy. A carbon payment system is used by a modeled GeOSIRIS policy to give incentives to emission reductions. The policy can be governed at various administrative levels, such as province or district. Rather than defending a specific section of land from deforestation, scope of work for GeOSIRIS projects would be on regional or national scale, by setting a certain price to every ton of carbon dioxide emitted $\left(\$ / \mathrm{tCO}_{2} \mathrm{e}\right)$. The GeOSIRIS model assumes forest users encounter a trade-off between the carbon revenue obtained by protecting the forests and the agricultural revenue obtained from deforesting the land. Given some variables such as a proposed carbon price and maps of previous deforestation, the model predicts how carbon emissions, deforestation, and agricultural and carbon revenues would change if such policy were implemented [7].
The model designs balance incentives to lower usually high deforestation emissions with incentives to keep usually low deforestation emissions. Approximations of emission reductions under REDD depend significantly on the degree to which demand for tropical agriculture in the borderline generates leakage. This emphasizes the potential importance to REDD of balancing strategies to supply agricultural needs outside the forest borderline [6]. The purposes of this study were to measure deforestation and carbon emissions in period of 2005-2010 in Indonesia and to find out the incentive value to be paid by the government.

\section{MATERIAL AND MethodS}

\subsection{Data used}

This study used data from

https://clarklabs.org/download/terrset-tutorial-data/, accessed on April 4, 2017, consisting of: (a) forest cover maps in 2005 and 2010, deforestation map 2005-2010 (see figure 1); (b) map of potential driver variables for deforestation, consisting of maps: slope, elevation, logarithmic distance to the nearest road, distance from the provincial capital, national park map, and plantation area map. These data are global data with spatial resolution of $3 \mathrm{~km} \times 3 \mathrm{~km}$. These data include global data that can be used for monitoring a large area (such as the whole Indonesia), due to the availability of sufficient data. However, for more specific planning, medium and detail scale data are needed to obtain more accurate results.

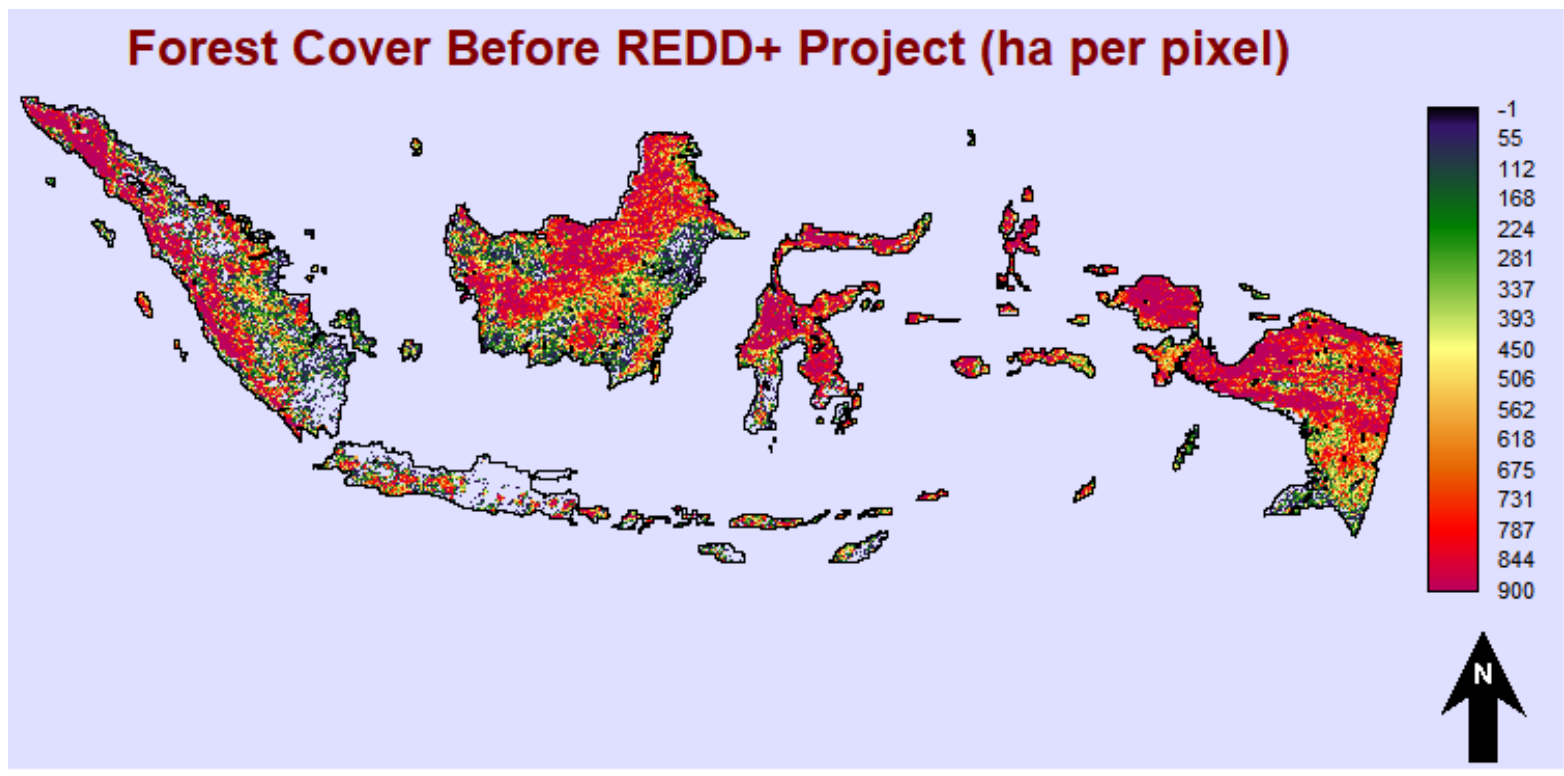

Fig. 1: Forest Area in Indonesia.

The disadvantage of these data is that the spatial resolution is too small (where one pixel represents an area of $900 \mathrm{ha}$ ). Therefore, areas with less than 900 ha (one pixel) will be combined into a more dominant class. The map actually covered the entire territory of Indonesia. For this study other than covering Indonesia, it was also cropped to cover Kalimantan and Sumatra Islands.

The GeOSIRIS model in REDD impact calculations is based on an enhanced OSIRIS model [7]. The flow chart of the GeOSIRIS modeling stage is presented in figure 2. 
In general, GeOSIRIS model has two main steps: (1) regression analysis, where the regression coefficient(s) and Effective Opportunity Cost image are calculated, and (2) calculations of proportional national change in agricultural price, output images (deforestation and emission), output image on administrative level decisions then the summary Excel spreadsheet is generated.

\subsection{Regression Analysis}

Stage of activity in this research refers to Eastman [9]. The regression step of the GeOSIRIS modeler calculates the correlation between deforestation and some individual variables (14 variables), including agricultural revenue. There are several options to classify this regression, where GeOSIRIS will run a separate regression for several different classes. These classes can be based on the amount of preexisting forest cover or geographic regions, such as provinces or districts (for geographic stratification).

This study is based on geographic regions, for Indonesia such as provinces (33 provinces) or districts (426 districts), For Sumatra Island such as provinces (13 provinces) or districts (131 districts) and for Kalimantan Island, such as provinces ( 5 provinces) or districts ( 55 districts).

The regression model used in this study is Poisson regression, in which the deforestation is counted by assuming that each pixel is composed of smaller subsections which may be individually deforested [9]. The Poisson regression uses the following formula:

$E(Y / X)=e^{\sum_{i=0}^{i=N} B t . X t}$

$\mathrm{E}(Y \mid X)=m \sum B i X i \quad i=N i=0$

where:

$\mathrm{E}(Y \mid X)=$ the expected count of deforestation (Y) given certain input conditions $(X)$

$X i=$ independent variable $(\mathrm{X} 0=1$ for the constant term $)$

$B i=$ variable coefficients (or parameters)

The model parameters consist of external variables (economic variables) and parameters that affect the price of agricultural products. Net Present Value formula:

$N P V=\sum_{t=1}^{T}(B t-C t)(1-i)^{-t}$

where:

$\mathrm{Bt}=$ total revenue generated in year $\mathrm{t}$,

$\mathrm{Ct}=$ total costs in year $\mathrm{t}$,

$\mathrm{i}=$ interest rate

$\mathrm{T}=$ expected lifetime $(5$ years $)$

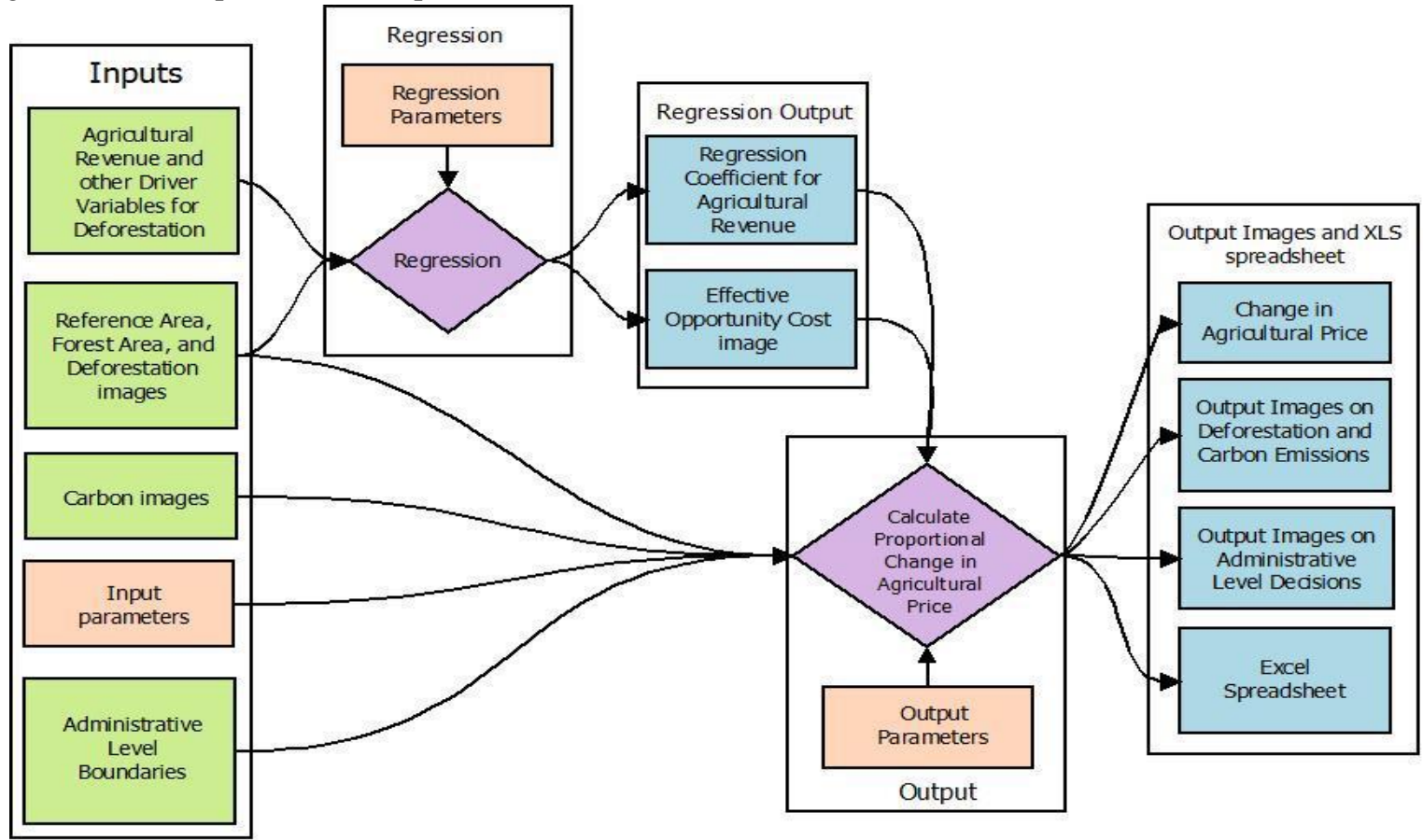

Fig. 2: Flowchart Stage of Research Activities

The GeOSIRIS model can be applied at different administrative levels, such as the district or provincial level. Image files are inputted in the administrative levels table of the input image files panel. The emission factor map is used to calculate the amount of $\mathrm{CO}_{2}$ (in tons) that will be emitted per hectare of deforestation. There are three components for the emission factor in the GeOSIRIS model: soil carbon, above and below-ground carbon, and peat. The calculations of the emission factor for each pixel are:

$E=(A \mathrm{~B}+\mathrm{SC} * f s) * 3.67$ where peat $\mathrm{P}=0$

$E=A \mathrm{~B} * 3.67+f p$ where peat $P>0$ 
where:

$E=$ emission factor $(t C O 2 \mathrm{e} / \mathrm{ha})$

$A \mathrm{~B}=$ above and ground carbon

$S \mathrm{C}=$ soil carbon

$f s=$ soil carbon factor

$f p=$ emission factor for peat soil

\subsection{Calculating the Proportional Change in Agricultural Price}

The GeOSIRIS model compares two consecutive values of changes in agricultural product price to see whether the value is appropriate. The model will keep on going until either the precision model or the maximum number of iterations is exceeded. The last iteration value obtained will be used for final calculation. Analysis of changes in agricultural prices, where proportional changes in agricultural prices are calculated, the image as a result of the analysis, and summary of the calculation results (in Excel worksheet) are then generated.

The final proportional change in the price of agricultural product is calculated in the output parameters panel. An iterative loop and two input parameters, which are model precision and maximum number of iterations, are used in this calculation. The price change is then calculated as the sum of endogenous change and exogenous change.

Change in Agricultural Price $=$ endogenous change (independent) + exogenous changes

Endogenous Change

$$
=\left[\frac{\text { Deforestati on without REDD }}{\text { Deforestati on with REDD }}\right]^{\theta}
$$

where:

the exponent $\mathrm{e}=$ price elasticity

The model compares two successive values in the change of agricultural price to see if they are within the model precision value. If they are, then the most recent iteration value is used for the final calculations. The model will continue to run until two successive values meet the model precision criteria, or the maximum number of iterations is exceeded, in which case the model terminates without performing any final calculations.

The model parameters are economic and those affecting the price of agriculture products. The price elasticity is a measure on how sensitive the agriculture production price is to the change in deforestation. The external factors causing the increase in agricultural price (exogenous change) is a part of the final change in agricultural price as shown in figure 3 .

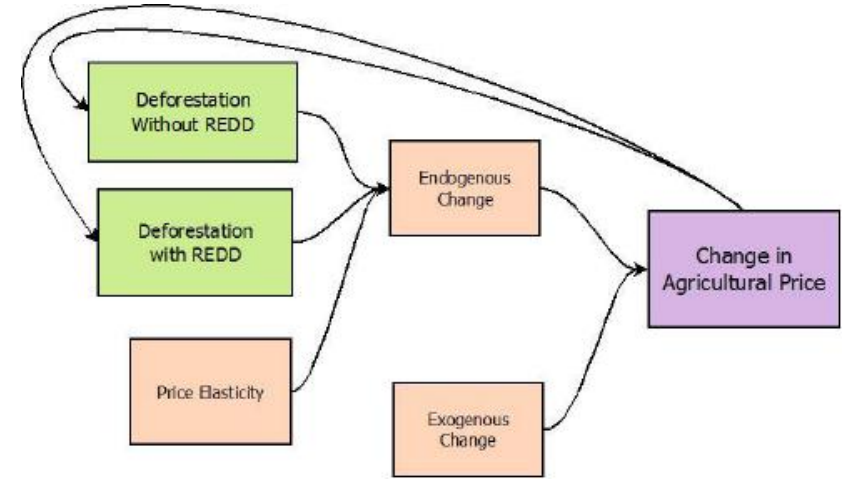

Fig. 3: The Exogenous Increasing in Agricultural Price.

\section{RESULTS AND DISCUSSION}

\subsection{Deforestation}

The total forest area in Indonesia in 2005 was 93.02 million ha or about $53.58 \%$ of the whole Indonesia. It consisted of 13.04 million ha $(14.02 \%)$ peatland forest and of 79.98 million ha $(85.98 \%)$ non-peatland forest or mineral forest. Based on forest type, it consisted of primary forest and secondary forest. In the period of 2005-2010 deforestation in Indonesia was 4.65 million ha, comprising 1.70 million ha $(36.56 \%)$ of peatland forests and 2.95 million ha $(63.44 \%)$ of mineral forests. The rate of deforestation at forest area was $4.99 \%$, at peatland forest was $13.03 \%$ and at non-peatland forest was 3.68, as presented in table 1 and figure 4 .

Deforestation that occurred at mineral forests was higher than at peatland forests because people prefer to utilize forests in mineral land first, where accessibility is easier and the existence of forests is also wider. Reduced forests in mineral land would then trigger people to take advantage of peatland forests.

The deforestation was relatively similar to the results of [13]. Refer to [13] deforestation at Indonesia in the period 2006-2011 amounted to 3.84 million ha $(5.04 \%)$, namely deforestation at peatland forests of 1.28 million ha $(33.29 \%)$ and deforestation at mineral land (nonpeatland) of 2.61 million ha $(66.71 \%)$. 


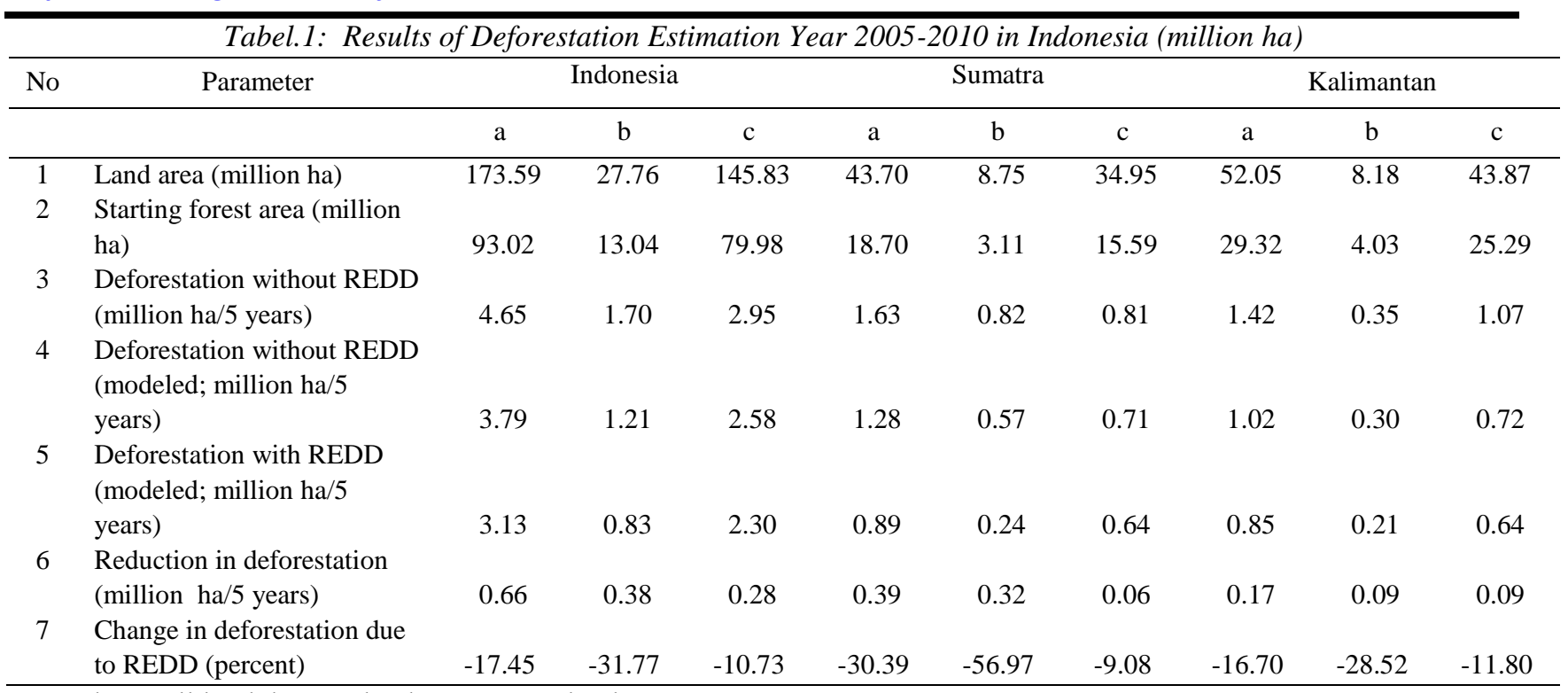

Remark: $\mathrm{a}=$ all land, $\mathrm{b}=$ peatland, $\mathrm{c}=$ non peatland

Meanwhile deforestation at Sumatra in the period 20062011 amounted to 1.92 million ha $(7.75 \%)$, namely deforestation at peatland forests of 0.64 million ha $(33.17$ $\%)$ and deforestation at mineral land (non-peatland) of 1.28 million ha $(66.83 \%)$. In Kalimantan island in the period 2006-2011 also amounted to 1.48 million ha $(4.20 \%)$, namely deforestation at peatland forests of 0.34 million ha $(22.60 \%)$ and deforestation at mineral land (non-peatland) of 1.15 million ha $(77.40 \%)$. Although the amount of deforestation is not exactly the same, but show a relatively similar pattern.

The rate of deforestation in Sumatra was higher than both deforestations occurred in Kalimantan Island and Indonesia over the same period. Deforestation in Sumatra Island was $8.74 \%$ while in Indonesia was 4.99 $\%$ and in Kalimantan Island was $4.84 \%$. The same condition also occurs at the rate of deforestation in peat forests and also mineral forests.

Based on type of forest, the rate of deforestation at peatland forest in Sumatra $(26.26 \%)$ was higher than Kalimantan Islands (8.68\%) and Indonesia (13.01\%).

The condition is triggered by the conversion of forests as oil palm plantations and also industrial plantations (pulp) in the center on the island of Sumatra and also the island of Kalimantan.

Furthermore, Refer [11] declared deforestation of primary forest at Kalimantan in 2000-2012 amounted to 2.377 million ha, comprising of deforestation at wetland forest 0.897 million ha and at dryland forest 1.390 million ha. The rate of deforestation of total primary forest was $7.92 \%$, at wetland forest was $5.25 \%$, and at dryland forest. Meanwhile at Sumatra Sumatra Island experienced intensive forest clearance which resulted in the conversion of $70 \%$ of the island's forest area until 2010.

Research conducted by [11], in the period 2000-2009, on the island of Sumatra deforestation occurred of 3.71 million ha or $23.92 \%$ of deforestation that occurred in Indonesia. The largest contributor to deforestation on Sumatra Island is Riau Province at $31.42 \%$, while Bengkulu Province is the region with the lowest deforestation of $3.53 \%$.

The rate of deforestation at Kalimantan and Sumatra Islands varied depending on the level of spatial resolution of data sources used. Research used Landsat Image data, therefore he got larger amount of deforestation. This was because spatial resolution of the image was $30 \mathrm{~m}$, more meticulous than the global data used in this study with spatial resolution of $3 \mathrm{~km}$ [11]. The deforestation in 2005-2010 happened as a result of government policy in the development of agricultural areas, the development of oil palm plantations and industrial plantations.

This is in line with the findings of study of expansion of agricultural policy, timber extraction and infrastructure expansion [9]. The main reasons of forest cover deficit in Kalimantan were related to the expansion of worldwide markets for pulp, wood and palm oil [15,17]. While Margono [12] asserted that in the period of 2000-2010 the cause of deforestation was the expansion of agricultural areas, especially palm oil plantations, expansion of pulp and paper plantation industrial areas and industrial forest clearance. Based on the figure 4 areas with relatively flat up to undulating topography and relatively easy accesibility (with existing rivers), it is a priority area for forest exploitation, thus causing the area to have higher deforestation rates (yellow to red). 


\section{Deforestation with REDD (ha/5 yrs; modeled)}

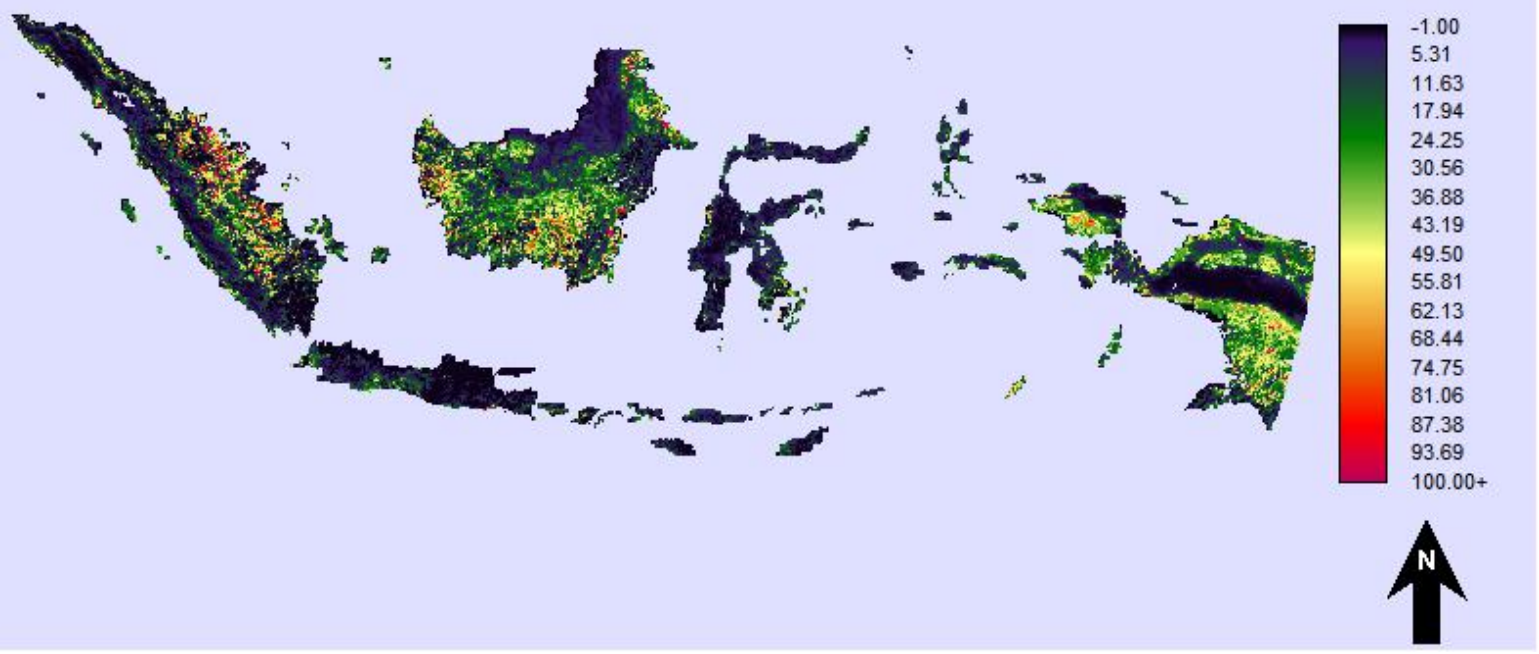

(a) with REDD

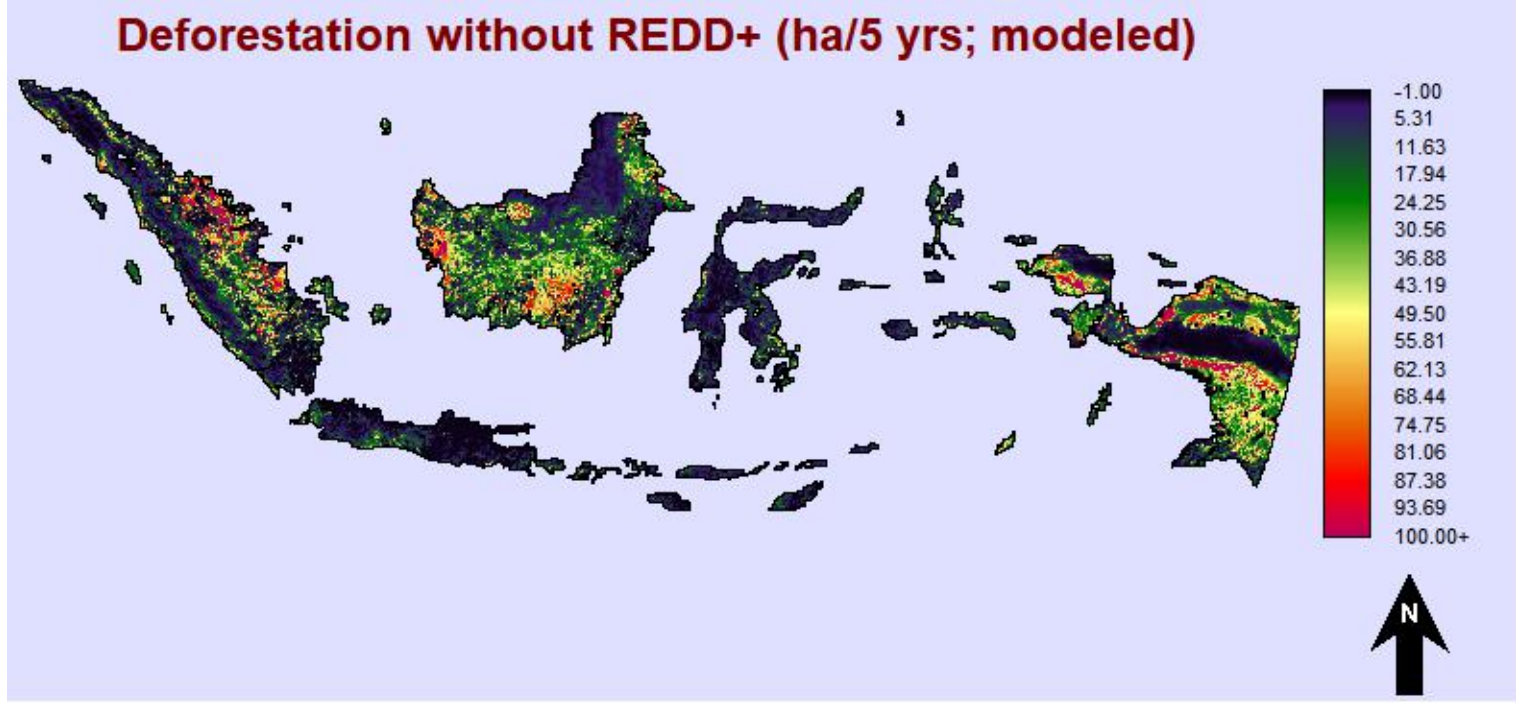

(b) Without REDD

Fig. 4: Map of Deforestation at Indonesia Country.

While areas with topographic hills to mountains (the existence of roads is very limited), then the area of forest is still relatively not yet logged, so rate of deforestation is relatively lower (blue to green).

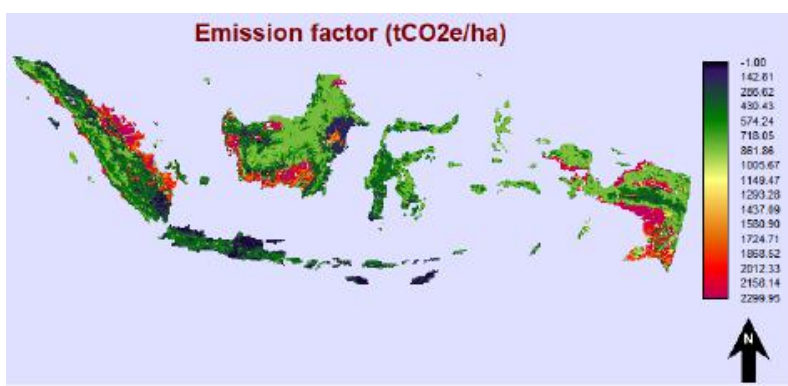

a Emission Factor
3.2 Carbon Emissions The impact of REDD

Implementation of REDD policies, which have an impact on reducing forest degradation, also directly impact on reductions of carbon emissions. Based on the variables affecting deforestation, carbon emissions and peat swamp factors (figure 5) have a strong effect to deforestation.

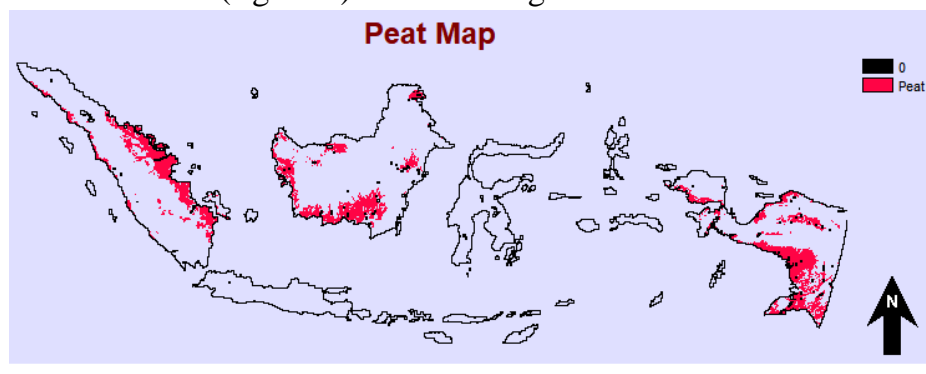

b. Peat swamp

Fig. 5 : Emission Factor and Peat Swap at Indonesia Country 
Based on figure 5, at Sumatra island, emission factors in Riau Province, Riau Islands, South Sumatra and Bangka Belitung have relatively higher value compared to other provinces. This is related to the existence of large peatland forest located in the area. Conversion of peatland forest into palm oil plantations causes the carbon emission factor to be higher. Meanwhile at Kalimantan island, carbon emission factors in West Kalimantan
Province and Central Kalimantan have relatively higher value compared to other provinces.

This is related to the presence of large peatland forest located in this area, while peatland is the highest contributor to emissions. Implementation The REDD policy at Indonesia, Sumatra island and Kalimantan island as presented in figure 6 and table 3 .

\section{Carbon emissions with REDD (modeled; tCO2e/5yrs)}

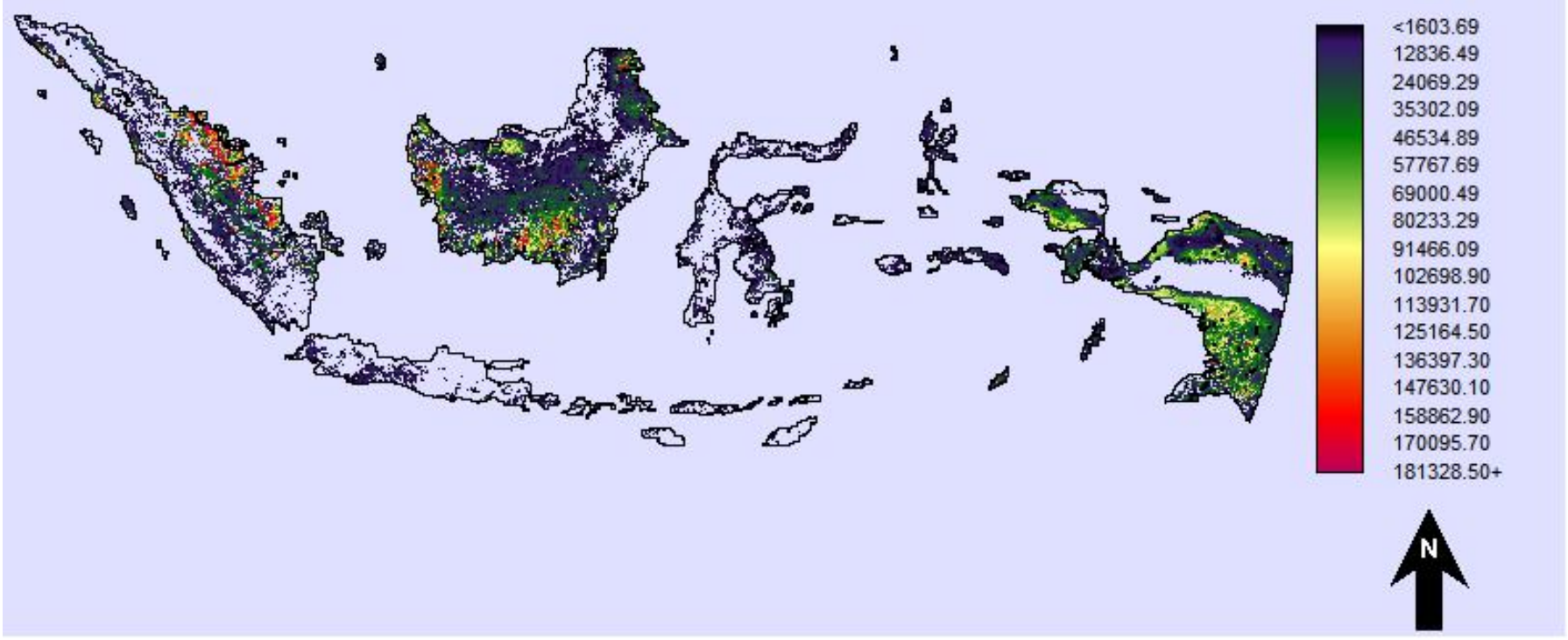

a. With REDD

\section{Carbon emissions without REDD (tCO2e/5 yrs; modeled)}

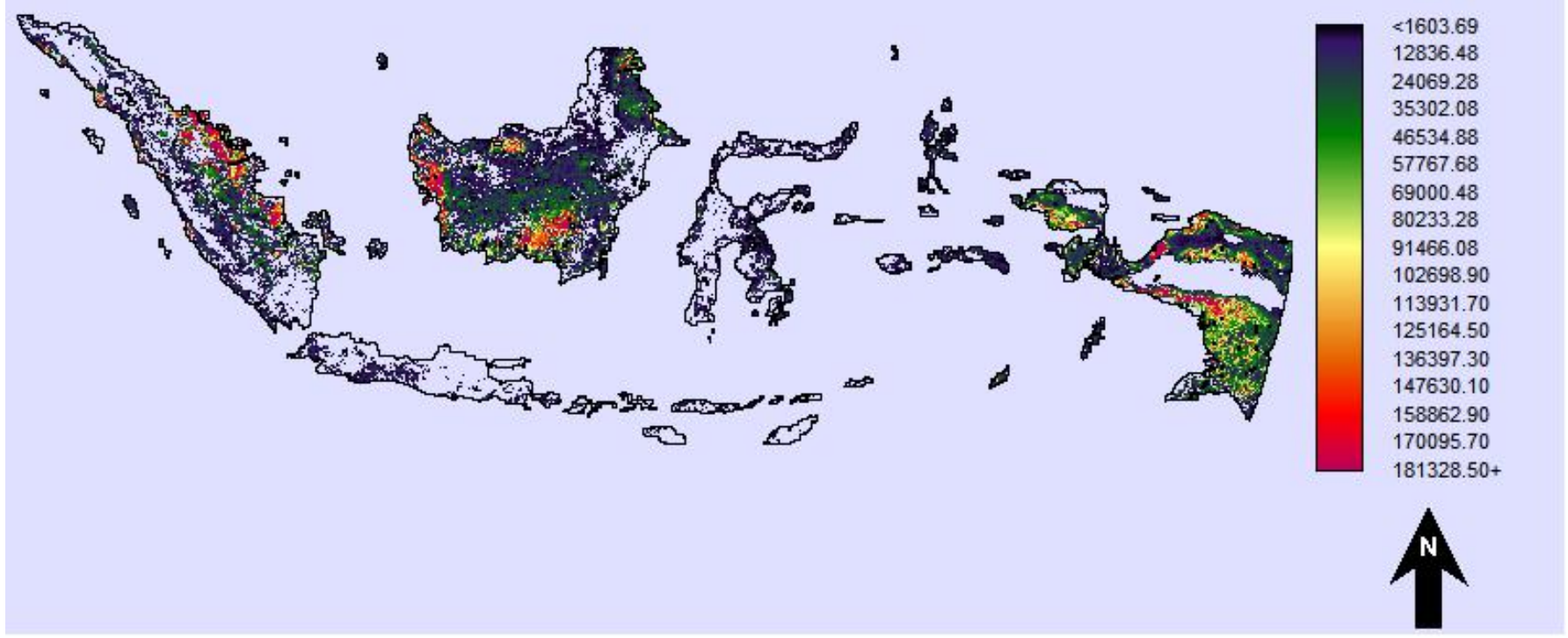

b. Without REDD

Fig. 6: Map of Carbon Emission in Indonesia 
Tabel.3: Result of carbon emission expectation year 2005- 2010 in Indonesia (x million ha)

\begin{tabular}{|c|c|c|c|c|c|c|c|c|c|c|}
\hline \multirow[t]{2}{*}{ No } & \multirow[t]{2}{*}{ Parameter } & \multicolumn{3}{|c|}{ Indonesia } & \multicolumn{3}{|c|}{ Sumatra } & \multicolumn{3}{|c|}{ Kalimantan } \\
\hline & & $\mathrm{a}$ & $\mathrm{b}$ & $\mathrm{c}$ & $\mathrm{a}$ & $\mathrm{b}$ & $\mathrm{c}$ & $\mathrm{a}$ & $\mathrm{b}$ & c \\
\hline 1 & $\begin{array}{l}\text { Emittable } \mathrm{CO}_{2} \text { from } \\
\text { forest carbon stock } \\
\text { (estimated; } \mathrm{t} \mathrm{Mg} \mathrm{CO} \text { ) }\end{array}$ & 84.64 & 28.50 & 56.14 & 16.79 & 6.80 & 9.99 & 27.16 & 8.76 & 18.40 \\
\hline 2 & $\begin{array}{l}\text { Emissions without } \\
\text { REDD }\end{array}$ & & & & & & & & & \\
\hline & (estimated; $\mathrm{tCO}_{2} / 5$ years) & 5.65 & 3.72 & 1.93 & 2.31 & 1.82 & 0.50 & 1.39 & 0.74 & 0.65 \\
\hline 3 & $\begin{array}{l}\text { Emissions without } \\
\text { REDD } \\
\text { (modelled; } \mathrm{tCO}_{2} / 5 \text { years) }\end{array}$ & 4.41 & 2.65 & 1.76 & 1.66 & 1.25 & 0.41 & 1.10 & 0.64 & 0.46 \\
\hline 4 & $\begin{array}{l}\text { National reference level } \\
\text { of emissions }\left(\mathrm{tCO}_{2} \mathrm{e} / 5\right. \\
\text { years) }\end{array}$ & 4.41 & - & - & 1.66 & -.00 & -.00 & 1.10 & -.00 & -.00 \\
\hline 5 & $\begin{array}{l}\text { Emissions with REDD } \\
\text { (modelled; } \mathrm{tCO}_{2} / 5 \text { years) }\end{array}$ & 3.32 & 1.79 & 1.53 & 0.88 & 0.53 & 0.35 & 0.85 & 0.46 & 0.40 \\
\hline 6 & $\begin{array}{l}\text { Gross emission } \\
\text { reductions }\left(\mathrm{tCO}_{2} \mathrm{e} / 5\right. \\
\text { years) }\end{array}$ & 1.10 & 0.86 & 0.24 & 0.79 & 0.72 & 0.07 & 0.27 & 0.19 & 0.07 \\
\hline 7 & $\begin{array}{l}\text { Gross emission increases } \\
\left(\mathrm{tCO}_{2} \mathrm{e} / 5 \text { years }\right)\end{array}$ & 0.004 & 0.00 & 0.00 & 0.01 & 0.00 & 0.01 & 0.02 & 0.01 & 0.01 \\
\hline 8 & $\begin{array}{l}\text { Net emission reductions } \\
\left(\mathrm{tCO}_{2} \mathrm{e} / 5 \text { years }\right)\end{array}$ & 1.09 & 0.86 & 0.23 & 0.78 & 0.72 & 0.05 & 0.25 & 0.18 & 0.06 \\
\hline 9 & $\begin{array}{l}\text { Credited emission } \\
\text { reductions }\left(\mathrm{tCO}_{2} \mathrm{e} / 5\right. \\
\text { years) }\end{array}$ & 1.09 & & & 0.78 & & & 0.25 & & \\
\hline 10 & $\begin{array}{l}\text { Change in emissions due } \\
\text { to REDD (percent) }\end{array}$ & -24.75 & -32.42 & -13.22 & -46.83 & -57.79 & -13.17 & -22.29 & -28.30 & -14.02 \\
\hline
\end{tabular}

Remark: $\mathrm{a}=$ all land, $\mathrm{b}=$ peatland, $\mathrm{c}=$ non peatland

Refer table 3, the forest emissions (emitable $\mathrm{CO}_{2}$ ) at Indonesia was 84.64 million $\mathrm{tCO}_{2} \mathrm{e}$, donation from peat land forest 28.50 million $\mathrm{tCO}_{2} \mathrm{e}(33.37 \%)$ and from mineral forest 56.14 million tCO2e $(66.33 \%)$. Based on spatial distribution, the forest emissions (emitable $\mathrm{CO}_{2}$ ) at Sumatra Island was 16.79 million $\mathrm{tCO}_{2} \mathrm{e}$, donation from peatland forest 6.80 million $\mathrm{tCO}_{2} \mathrm{e}(40,48 \%)$ and from mineral forest 9.99 million $\mathrm{tCO}_{2} \mathrm{e}(59,52 \%)$. Meanwhile the forest emissions (emitable $\mathrm{CO}_{2}$ ) at Kalimantan Island was 27.16 million $\mathrm{tCO}_{2} \mathrm{e}$, donation from peatland forest 8.76 million $\mathrm{tCO}_{2} \mathrm{e}(32.25 \%)$ and from mineral forest 18.40 million $\mathrm{tCO}_{2} \mathrm{e}(67.75 \%)$

Impact of REDD policy in Indonesia targeted carbon emissions of 4.41 million ha. Meanwhile, the gross emission reduction that could be obtained was 3.32 million $\mathrm{tCO}_{2} \mathrm{e}$, and emission that could be absorbed by forests was 1.09 million tCO2e. Distribution on Sumatra island, targeted carbon emissions of 1.66 million ha. Meanwhile, the gross emission reduction that could be obtained was 0.88 million $\mathrm{tCO}_{2} \mathrm{e}$, and emissions that could be absorbed by forests was 0.79 million $\mathrm{tCO}_{2} \mathrm{e}$.

Meanwhile implementation REDD policy at Kalimantan island, targeted carbon emissions of 1.10 million ha. The gross emission reduction that could be obtained was 0.85 million $\mathrm{tCO}_{2} \mathrm{e}$, and emissions that could be absorbed by forests was 0.27 million tCO2e.

Both islands (Kalimantan and Sumatra) contribute carbon emissions as much as $69.14 \%$. Meanwhile, according to [1] stated that Indonesia had various emission levels from deforestation on each island. The highest emissions came from Sumatra, which were almost $56 \%$ of all emissions, and the second was Kalimantan with $28 \%$, thus total for both islands was $84 \%$. Therefore, it is important to focus on these two islands in implementing emission reduction strategies. The high emissions from Sumatra and Kalimantan were caused by the high deforestation rate on both islands, reaching $77 \%$ of Indonesia's total deforestation.

Meanwhile [2] Deforestation in Sumatra contributed the greatest importance of the existing focus on clearance of peatland forest.

The REDD policy was capable of reducing carbon emissions at Indonesia by 1.09 million $\mathrm{tCO}_{2} \mathrm{e}$ (24.753\%). Meanwhile, the reduction of carbon emission in peatland forest area was 0.86 million $\mathrm{tCO}_{2} \mathrm{e}(28.30 \%)$ and in mineral soil forest area was 0.23 million $\mathrm{tCO}_{2} \mathrm{e}(14.02 \%)$. The REDD policy was capable of reducing carbon emissions at Sumatra Island by 0.78 million $\mathrm{tCO}_{2} \mathrm{e}$

Page | 783 
$(46.83 \%)$. Meanwhile, the reduction of carbon emission in peatland forest area was 0.72 million $\mathrm{tCO}_{2} \mathrm{e}(28.30 \%)$ and in mineral soil forest area was 0.05 million tCO2e (14.02 $\%)$.

The REDD policy was capable of reducing carbon emissions at Kalimantan Island by 0.25 million $\mathrm{tCO}_{2} \mathrm{e}$ (22.29\%). Meanwhile, the reduction of carbon emission in peatland forest area was 0.18 million $\mathrm{tCO}_{2} \mathrm{e}(28.30 \%)$ and in mineral soil forest area was 0.06 million $\mathrm{tCO}_{2} \mathrm{e}(14.02$ $\%)$.

The reduction in carbon emission levels at Indonesia $(24.75 \%)$ was lower than the reduced emission carbon that occurred at Sumatra Islands $(46.83 \%$, but it was higher than the reduced emission carbon that occurred at Kalimantan Islands (22.29\%) in the same period.

The carbon emission reduction at Indonesia was 1.091 million $\mathrm{tCO}_{2} \mathrm{e}(24.75 \%)$, comprising of 858 million $(32.42 \%)$ at peatland forests and a decrease in mineral soil carbon emissions of 233 million $\mathrm{tCO}_{2} \mathrm{e}(13.22 \%)$.

Meanwhile, the decline in carbon emissions in Sumatra island was 0.78 million $\mathrm{tCO}_{2} \mathrm{e}(46,83 \%)$, consisting of 0.72 million $\mathrm{tCO}_{2} \mathrm{e}(57.78 \%)$ at peatland forest and 0.05 million $\mathrm{tCO}_{2} \mathrm{e}(13.17 \%)$ at mineral soil. The decline carbon emissions in Kalimantan island was 245 million
$\mathrm{tCO}_{2} \mathrm{e}(22.29 \%)$, consisting of 180 million $\mathrm{tCO}_{2} \mathrm{e}(28.52 \%)$ at peatland forest and 64 million $\mathrm{tCO}_{2} \mathrm{e}(14.22 \%)$ at mineral soil.

Changes in carbon emissions due to REDD were proportional to the rate of deforestation that occurred. The relatively smaller peatland forest area compared to the mineral forests caused the reductions deforestation rate (percentage of deforestation) in peatland forests to be greater than the rate of deforestation in mineral forests, with the same forest area.

Assuming that world carbon price was US $\$ 10 / \mathrm{tCO}_{2} \mathrm{e}$, impact of REDD Policy at Indonesia, Kalimantan Island and Sumatra were that the gross national revenue from carbon payments and allocation for local government presented in Table 4.

Tabel.4 : Economic Revenue Impact of REDD Policy at Indonesia (US\$ billion)

\begin{tabular}{|c|c|c|c|c|}
\hline No & Economic Revenue & Indonesia & Sumatra & Kalimantan \\
\hline 1 & $\begin{array}{l}\text { Gross national revenue from carbon payments } \\
\text { ( NPV -- } 5 \mathrm{yrs} \text { ) }\end{array}$ & 10.917 & 7.75 & 2.45 \\
\hline 2 & $\begin{array}{l}\text { Carbon payments to sub-national entities } \\
\text { ( NPV -- } 5 \text { yrs) }\end{array}$ & 9.178 & 6.78 & 2.15 \\
\hline 3 & $\begin{array}{l}\text { Net central government surplus/deficit from } \\
\text { carbon payments ( } \$ \text {, NPV -- } 5 \text { yrs) }\end{array}$ & 1.739 & 0.97 & 0.30 \\
\hline 4 & $\begin{array}{l}\text { Participan (number) } \\
\text { Province ( } \%, \text { number) }\end{array}$ & $70(23)$ & $58(7)$ & $80(4)$ \\
\hline & Distric ( $\%$, number $)$ & $66(281)$ & $64(84)$ & $78(43)$ \\
\hline
\end{tabular}

Refer table 4, if the REDD policies are applied to the territory of Indonesia, it will be gross national revenue from carbon payments (NPV, 5 years) would be $\$ 10.917$ billion, with allocation for local government (provincial and district) as incentives (NPV, 5 years) was \$ 9.178 billion $(84.07 \%)$. Net government surplus originating from carbon payments was US \$ 1.739 billion (NPV, 5 years.

For the REDD policies are applied to Sumatra island, it will be gross national revenue from carbon payments (NPV, 5 years) would be $\$ 7,75$ billion, with allocation for local government as incentives (NPV, 5 years) was \$ 6.78 billion (87.48\%). Net government surplus originating from carbon payments was US \$ 0.97 billion (NPV, 5 years).

If the REDD policies are applied to the territory of Kalimantan island, it will be gross national revenue from carbon payments (NPV, 5 years) would be $\$ 2.45$ billion, with allocation for local government as incentives (NPV, 5 years) was $\$ 2.15$ billion $(87.56 \%)$. Net government surplus originating from carbon payments was US \$ 0.30 billion (NPV, 5 years).

Results of the study [2] that calculated carbon emissions in Bolivia, GeOSIRIS could also be used to evaluate how much reduction of deforestation could be achieved with the price of alternative carbon. Refer [1] with international $\mathrm{CO}_{2}$ price of US\$ 5-50/tCO , we can simulation relationship carbon price with deforestation and emission at the Kalimantan Island, Sumatra and Indonesia as show on figure 7.

Based on figure 7, with a price of $\$ 10$ it could be reduced by about $17 \%-30 \%$ and at $\$ 50$ by around $40 \%-70 \%$. The increase in carbon prices will spur activities to protect the forests so that the forests will be better 
protected and deforestation will also occur. Conversely, if there is an increase in price of agricultural products, then the rate of deforestation will also increase, because more forest areas will be cultivated into agricultural areas. The relationship between carbon prices to deforestation and carbon emissions has the same pattern (refer to fig 7). The impact of rising carbon prices leads to increased deforestation as well as carbon emissions. The impact of rising carbon prices on forest areas in Sumatra has a

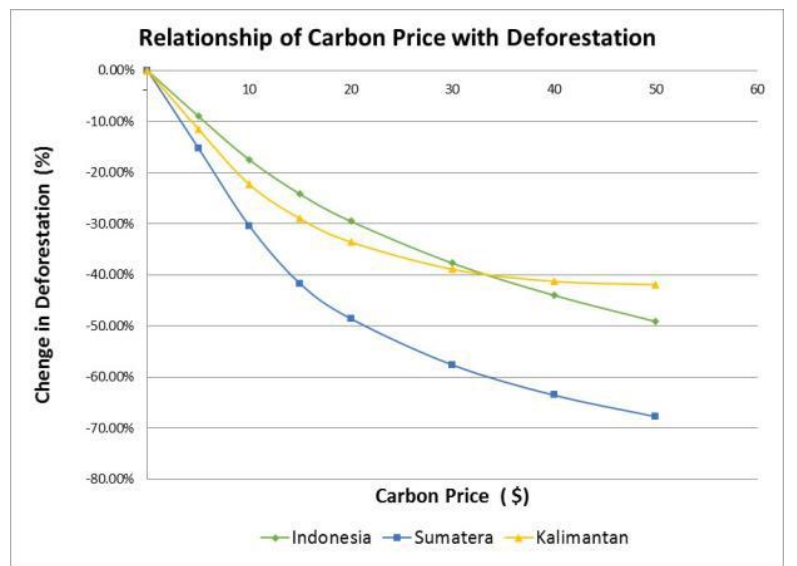

a. Price with Deforestation bigger impact than deforestation on the average of Indonesia and also forests in Kalimantan.

Similarly, a success in reducing deforestation is linearly related to reduction of carbon emissions. The more forests that can be protected from logging, the more economically beneficial they will be

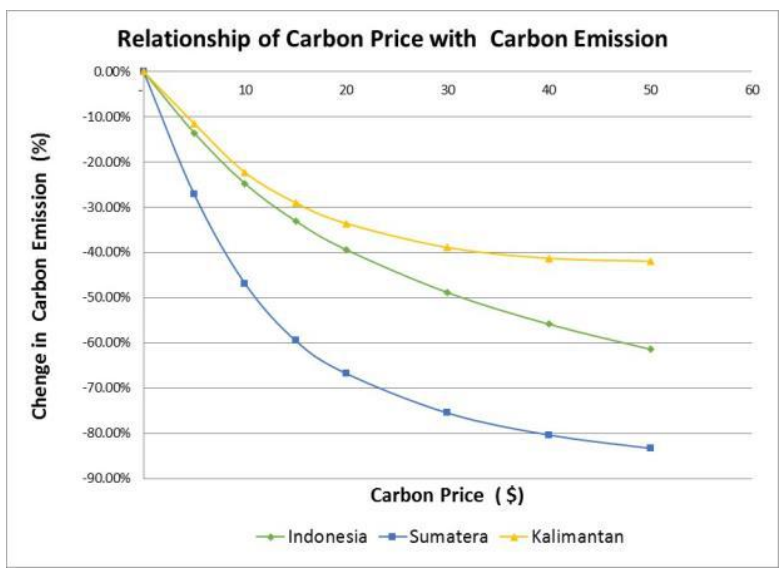

b. Price with Carbon Emission

Fig.7: Relationship of Carbon Price with Deforestation and Carbon Emission

\section{CONCLUSION}

In the period 2005-2010, deforestation at Indonesia was 4.65 million ha $(4.99 \%)$. The simulation result, impact of REDD policy could reduce deforestation at Indonesia by 0.66 million ha $(17.45 \%)$. With assumption that international carbon price of US\$ $10 / \mathrm{tCO} 2 \mathrm{e}$, the change of emissions due to REDD was $24.75 \%$, or reduced emissions by 1.09 million $\mathrm{tCO}_{2} \mathrm{e} / 5$ years. Finally, Gross National Revenue from carbon payments (NPV 5 years) was US\$ 10.917 billion, where incentivize emission reductions to sub-national entities (NPV, 5 years) was US\$ 9.178 billion and net central government surplus from carbon payments was US\$ 1.739 billion (NPV, 5 years).

\section{ACKNOWLEDGEMENTS}

A Thanks to the Head of Center for Research, Promotion and Cooperation, and Head of Research Division of Geospatial Information Agency of Indonesia (BIG) who have facilitated this research activity. Also, a huge thanks to Clark Labs that provided data.

\section{REFERENCES}

[1] Alliance I F C (2008) Reducing emissions from deforestation and forest degradation in Indonesia: IFCA consolidation report (Jakarta: Forestry Research and Development Agency, Ministry of Forestry of Republic of Indonesia
[2] Andersen L E, Busch J, Curran E, Ledezma J C, Mayorga J, and Bellier M (2012) Environmental and socio-economic consequences of forest carbon payments in Bolivia: Results of the OSIRIS model (Bolivia: Institute for Advanced Development Studies) p 35

[3] Barlow J, Gardner T A, Araujo I S, Ávila-Pires T C, Bonaldo A B, Costa J E, and Hoogmoed M S (2007) Proc of The National Academy of Sciences of the United States of America

[4] Bassi, A., Varma, K., \& Toppo, W. (2015). Forest ecosystem valuation study: Indonesia. United Nations Office for REDD Coordination in Indonesia (UNORCID).

[5] Bununu Y A, Ludin A N M, and Hosni N (2016) Proc 10th SEATUC Symposium (Tokyo: Shibaura Institute of Technology)

[6] Busch, J., Strassburg, B., Cattaneo, A., Lubowski, R., Bruner, A., Rice, R., ... \& Boltz, F. (2009). Comparing climate and cost impacts of reference levels for reducing emissions from deforestation. Environmental Research Letters, 4(4), 044006

[7] Eastman JR (2014) Manual Terrset Manual (Chapter Eight : Geosiris). Clark Labs, Clark University, Worcester, Massachussetts.

[8] FAO (2010) Global Forest Resources Assessment 2010 Country Report Indonesia Forest Resource Assessment (FRA) 2010/095 (Rome: UNFAO).

[9] Fuller, D. O., Jessup, T. C., \& Salim, A. (2004). Loss of forest cover in Kalimantan, Indonesia, since the 
1997-1998 El Nino. Conservation Biology, 18(1), 249-254.

[10] Hansen M C, Potapov P V, Moore R, Hancher M, Turubanova S, Tyukavina A, and Kommareddy A (2013) High-resolution global maps of 21st-century forest cover change (Science vol 34)

[11] Margono B A, Potapov P V, Turubanova S, Stolle F, and Hansen M C (2014) Nature Climate Change 4 730-735

[12] Margono B A, Turubanova S, Zhuravleva I, Potapov P, Tyukavina A, Baccini A, and Hansen M C (2012) Environmental Research Letters 7034010.

[13] MoEF (2016) National Forest Reference Emission Level for Deforestation and Forest Degradation: In the Context of Decision 1/CP.16 para 70 UNFCCC (Encourages developing country Parties to contribute to mitigation actions in the forest sector) (Jakarta: Directorate General of Climate Change. The Ministry of Environment and Forestry)

[14] Ministry of Forestry of the Republic of Indonesia (2008). C0nsolidation Report Reducing Emissions From Deforestation And Forest Degradation In Indonesia.

[15] Nawir A A, Murniati and Rumboko L 2007 Forest Rehabilitation in Indonesia: Where to After More Than Three Decades? (Bogor: CIFOR)

[16] Sumargo W, Nanggara S G, Nainggolan FA, Apriani I (2011) Portrait of Indonesia's Forest 2000-2009 1st Edition (Jakarta: Forest Watch Indonesia)

[17] Uryu Y, Mott C, Foead N, Yulianto K., Budiman, A, Setiabudi, F T, and Jaenicke J (2008) Deforestation, forest degradation, biodiversity loss and $\mathrm{CO} 2$ emissions in Riau, Sumatra, Indonesia (Jakarta: WWF Indonesia). 